\title{
PARTICIPATORY SOLID WASTE GOVERNANCE AND THE ROLE OF SOCIAL AND SOLIDARITY ECONOMY: EXPERIENCES FROM SÃO PAULO, BRAZIL
}

\author{
Jutta Gutberlet ${ }^{1, \star}$, Gina Rizpah Besen ${ }^{2}$ and Leandro Pereira Morais ${ }^{3}$ \\ ${ }^{1}$ University of Victoria - Geography, 3800 Finnerty Road PO BOX 3060 STN CSC , Victoria, British Columbia V8W 3R4, Canada \\ 2 University of Sao Paulo, Instituto de Energia e Ambiente, São Paulo, Brazil \\ ${ }^{3}$ UNESP, Campus de Araraquara, Araraquara, São Paulo, Brazil
}

Article Info:

Received:

21 February 2020

Revised:

22 June 2020

Accepted:

23 June 2020

Available online:

5 October 2020

Keywords:

Environmental governance

Social and Solidarity Economy

Waste management

Waste picker organizations

Networks

Brazil

\begin{abstract}
Waste governance is emerging as transdisciplinary and inter-sectoral approach to waste management and policy, overcoming primarily prescriptive engineering perspectives of waste. The process of governing waste involves the articulation of different structures, institutions, policies, practices and actors. Paying attention to issues of power, scale, and equity are important in the search for more democratic practices. Innovative forms of governance are emerging as decentralized, participatory and inclusive, focused on waste reduction and resource recovery. Social and Solidarity Economy (SSE) is an innovative alternative in generating work and income and a response in favor of social and labor inclusion. It can also be considered as a new, more humane and inclusive development model. With this article we aim to provide practical knowledge on the contributions of grassroots organizations and networks in waste management, supporting the discussion of waste governance in the context of the SSE. We present different experiences of waste picker organizations in the metropolitan region of São Paulo, Brazil to showcase their assets and to discuss prevailing challenges. Employing the SSE as a new development model allows us to address everyday issues of waste generation, management and governance in Brazilian cities and in other parts of the world; particularly from the perspective of organized waste pickers in associations, cooperatives and networks. This is a development paradigm which goes beyond just economic considerations, as highlighted with examples from waste management.
\end{abstract}

\section{INTRODUCTION}

Cities worldwide generate between 7 and 10 billion tonnes of waste every year from households, commerce, industry and construction; a number that is expected to double by 2030 , given the rapid urban growth trend (UNEP \& ISWA, 2015). Particularly in cities within lower income countries, waste collection is limited and typically only reaches high income neighbourhoods. Approximately 2 billion people in lower income countries are without access to solid waste collection and even if collected, the waste often ends up in open dumps. Worldwide, this represents $33 \%$ of urban waste mounting to a serious and global health hazard (Kaza, Yao, Bhada-Tata \& Van Woerden, 2018). Basic waste management challenges include open dumps, uncontrolled dumping, open burning and inadequate access to waste services and unsafe recycling practices, particularly in informal neighbourhoods (Wilson, et al., 2015).

Local governments encounter multiple financial and technical constraints as well as numerous challenges in waste management, with the increase in volume, the growing material complexity or the difficulties with source separation. Mismanaged waste becomes a global wicked problem, particularly noticeable when it washes up in places far from its origin, causing environmental contamination, entanglement for animals and affecting the food chain. Many everyday challenges, such as poverty, pollution, flooding, poor health, littering and environmental degradation are closely related to the lack of proper answers to waste issues. Environmental governance (Lemos \& Agrawal, 2014) plays a key role in addressing these challenges, involving all scales (global, national, regional and local) and all sectors from government, and business to civil society at large (UN Environment, 2019). Complex environmental problems are always closely related with other policy areas (Jordan \& Lenschow, 2010), yet efforts to overcome the separation and boundaries as a result of sector approaches in gover- 
nance have not made sufficient progress (Adelle \& Nilsson, 2015). A better understanding of the reality, the hurdles, the missing links and the assets in waste governance in different countries and cities is required to achieve better waste management outcomes.

A key step towards reducing the environmental and health impacts of waste is to shift the perspective from regarding waste as a threat to seeing it as a resource that must be recovered. That is how waste pickers all over the world have always perceived waste, as a resource to support their livelihoods (Wilson et al., 2006, 2012; Chaturvedi, 2009; Samson, 2009; Scheinberg, Simpson \& Mol, 2011; Linzner \& Lange, 2013; Gutberlet, 2008; 2016). Today an estimated 15 to 20 million waste pickers work in waste recovery worldwide (ILO, 2013) and while these waste pickers are key environmental ambassadors operating in the circular economy, most of them work under unacceptable conditions (Wilson et al., 2015; Duan, Li \& Liu, 2017), exposed to health risks (Binion \& Gutberlet, 2012; Gutberlet \& Uddin, 2018), social exclusion and stigmatization.

Participatory waste governance, the focus of this paper, draws the attention to the integration of waste pickers in formal recycling, of which few examples have so far been discussed in the literature (Jaligot et al., 2016; Wilson et al., 2012; Jacobi \& Besen, 2011; Sembiring \& Nitivattananon, 2010).

Our case study is located in the metropolitan region of São Paulo (MRSP), Brazil, with 21 million inhabitants. The region has sanitary landfills and most of the formal city has regular waste collection services, but little to no formal recycling programs. Informal settlements are generally excluded from regular collection and open dumping becomes widespread. Very few municipalities in the MRSP have started programs for selective waste collection and recycling, and are working in co-production with organized waste pickers. These programs service mostly the central parts of the city, while in the periphery recycling happens informally, involving a majority of autonomous waste pickers.

Good governance and the sustainable management of solid waste links up with all of the 17 Sustainable Development Goals (SDGs) established under Agenda 2030. Particularly, goal number 12 proposes to ensure sustainable production and consumption patterns and specifically target 12.5 , demands a substantial reduction of waste generation through prevention, reduction, recycling and reuse, by 2030 (ONUBR, 2015). This requires consolidating a multi-scalar governance approach and the alignment of international, national and local actions (UN Environment, 2019). Strategies tackling sustainability through packaging design and product lifecycle, for example, that aim to reduce the impacts on natural resource extraction, can promote a 10 to 15 per cent reduction in global greenhouse gas emissions just from recycling and improvements in solid waste management, and between 15 and 20 per cent by including measures to prevent or reduce the production of waste (Wilson et al., 2015, p. 12).

One of the key objectives of the paper is to demonstrate the potential of participatory waste governance, specifically with the inclusion of waste pickers (organized in cooper- atives, associations or networks) in selective waste collection. We, further want to investigate the role of the Social and Solidarity Economy (SSE) (Moulaert \& Ailenei, 2005; Moulaert \& Nussbaumer, 2005) as an instrument supporting the integration of waste pickers and possibly as a driver for a new social and economic development model.

The next section introduces the two main concepts used as analytical framework: (a) waste governance and (a) social and solidarity economy. We then outline the methodology and describe the qualitative research strategy involving six waste picker networks and the national waste picker organization in the metropolitan region of São Paulo, providing a rational for the choice of our study region. The following section presents and discusses the results, drawing specific attention to the role of participatory governance and Social and Solidarity Economy in expanding the capabilities of waste pickers. We conclude with reflections on the assets waste picker organizations can bring in shaping participatory, environmental governance and some of the challenges organized waste pickers are facing, given the current situation in waste management in the region and beyond.

\section{ANALYTICAL RESEARCH FRAMEWORK}

\subsection{Waste governance}

Governance is about the organization of society or groups within it, as well as their decision-making structures and accountability. It is a broad, diverse and complex concept which takes different shapes in different geographic contexts (Andrews, 2008). "Governance determines who has power, who makes decisions, how other players make their voice heard and how account is rendered" (Institute on Governance, n.d.). The need for governance exists anytime a group of people come together to address a specific issue, e.g. waste management. Governance also concerns the "performance of the government, including public and private sectors, global and local arrangements, formal structures, informal norms and practices, and spontaneous and intentional systems of control" (Ezeah \& Roberts, 2015, p. 122). Governance practices are shaped by the interactions of different social actors, which often come with diverse, conflictive, antagonistic interests, views and values, which governance is supposed to settle or reconcile. In that process, rules able to regulate and intermediate negotiation processes are crucial, allowing to arrive at a common understanding on the problems to be solved and at possible strategies to overcome these problems.

Waste governance takes an inter-sectoral approach to waste management with a focus on policies and regulations, as well as institutional arrangements that delimit how decisions are made, who participates in the deliberations and how work is carried out. Thus, from a waste governance perspective, there are examples where some governments are currently moving away from a primarily prescriptive, engineering approach (Bulkeley et al., 2005; Moore, 2012) towards forms that are more inclusive of different actors, different methods and diverse perspectives.

Waste is a noticeable proof of inefficiency and wrong decision making in any environment and requires inno- 
vative governance solutions. Good waste governance requires the reconceptualization of waste as a resource, it takes an inclusive approach to waste management that allows e. g. grassroots waste actors (waste pickers, smallscale waste entrepreneurs, community-based organizations, non-governmental organizations, or citizens at large) to participate and it encourages innovative approaches to prevent the generation of waste and wasted resources.

The process of governing waste involves the articulation of different institutions, structures, technologies, practices and actors; and issues of power, scale, and equity are important in shaping the outcomes. Innovative forms of governance are decentralized, participatory and inclusive, focused on waste reduction and resource recovery. These attributes allow for the socio-productive inclusion of waste pickers and the achievement of greater sustainability (e.g. zero waste, circular economy). Good waste governance also addresses: poverty reduction, builds community resilience, tackles climate change and increases environmental sustainability; besides working towards reduction, reuse and recycling.

In the global context waste governance is one of the biggest environmental and urban challenges (Hoornweg Bhada-Tata, 2012), regardless of city size and political priority (UN - Habitat, 2010). Waste is intrinsically related to environmental health issues and environmental governance is relevant specifically given the challenges cities are facing, with climate change, raising poverty, ecosystem degradation or pollution. Environmental governance is defined as "interventions aiming at changes in environment-related incentives, knowledge, institutions, decision making, and behaviors" (Lemos \& Agrawa, 2006, p. 298).

The state has an important role to play in shifting towards inclusive environmental governance (Adelle \& Nilsson, 2015), e.g. by ratifying and implementing conventions, promoting research, designing new policies, laws and regulations, and by supporting vulnerable populations, e.g. through Social and Solidarity Economy programs (Alvarez, 2015). In lower income countries, including Brazil, waste management problems are amplified by rapid urban growth, pressured and insufficient facilities, poor service delivery, lack of resources and often also lack of political will (Ezeah \& Roberts, 2015). Furthermore, the diversity of materials in solid waste and their specific forms of management makes governance more complex, insofar as it also involves unknown materials and new actors. Organic material mixed within inorganic waste also creates a wide range of other problems.

Waste pickers formalized in cooperatives or associations are important actors in waste governance (Asim et al., 2012; Dias, 2016; Fei et al., 2016; Gutberlet, 2015; Scheinberg, 2012; Velis, 2017; Velis et al., 2012; Wilson et al., 2006). Particularly in Latin America, their participation in municipal selective waste collection programs has not only created better local waste management and circular economy results, but has also generated 'socio-productive inclusion', which is defined as implementation of policies (SSE) that promote the organization of waste pickers and their integration into municipal waste management, generating income and providing better working conditions
(Fracalanza \& Besen, 2016). Selective waste collection operated by waste pickers is considered a successful 'social technology' (Rutkowski \& Rutkowski, 2015). Moreover, we argue that participatory governance is a prerequisite to effectively address urban waste problems in the global South.

As we will demonstrate ahead, the transversality of SSE actions, especially those related to economic, social and environmental contexts, constitutes a theoretical and practical platform closely related to the issue of waste governance in practice. The generation of work and income, combined with a greater involvement with work practices of recycling cooperatives and associations, for example, in addition to the participation in political decision-making bodies (such as public councils, when they exist) and the generation of environmental externalities, allow for the activity of many recycling cooperatives and associations to be connected with economic, social and environmental aspects.

Within these enterprises, it is expected that collective organizations along the lines of the SSE allow for the development of participatory and democratic governance, giving those involved the power of voice towards their working conditions and the enterprise in general. From an operational point of view, as we know, the activity of thousands of women and men in the collection, sorting and processing of recyclable materials has been increasingly recognized by society, in recent years. This is due, in large part, to the recognition of its economic and environmental relevance, in addition to the potential for social inclusion of a large contingent of people excluded from other work opportunities; people who live in social marginality and vulnerability (Millar, 2018). In Brazil, the collective organization of waste pickers in cooperatives and associations represents an important part of the SSE (IPEA, 2016). This fact allows for reciprocal strengthening of the SSE and the democratic and participatory management practices in waste picker cooperatives and associations.

\subsection{The Social and solidarity economy}

The SSE is understood as alternative economy generating work and income, as response to the demand for social and labor inclusion. For many, the SSE resembles an innovative, more humane and inclusive development model compared to the capitalist market driven economic development model (Morais, Dash \& Bacic, 2017). The SSE framework sees a diversity of economic and social practices, carrying out different activities including the production of goods, services, solidary finances, exchange of goods and services, fair trade and solidary consumption (Morais, 2013, 2014). According to Vieira, "as a concept, [SSE] has a triple nature. At the same time that it is an empirically verifiable object, it is also a social movement and a propositional theory of socioeconomic change" (2005, p. 56).

The existing terminological diversity was described by Moreno (1996), highlighting the most frequent terms: third sector; voluntary or independent sector; 'non-profit, philanthropic or charitable sector; non-governmental organizations (NGOs); intermediate sector; tax-free sector; and social and solidarity economy. Tremblay (2009) lists 
country-specific terminologies, such as Social Economy (USA and Canada), Solidarity Economy (Argentina, Brazil, Chile and Quebec), People's Economy (Asia), Associative Movements (Senegal and Turkey), Civil Society (South Africa) and Community Economic Development (Australia, New Zealand and Anglo Saxon Canada). The large number of different terms reflect the multiple modes of generation, performance and behavior that this sector manifests in different geographies, based on the specific historical, cultural, political or legal contexts (UN Inter-Agency Task Force on Social and Solidarity Economy, 2018). The following Table 1 summarizes some of the more widespread definitions, operating principles and respective entities of the SSE.

Alvarez synthetizes SSE as a set of socioeconomic practices that "combine cooperative entrepreneurship with the association of people seeking to meet needs" (2018, p. 6). SSE organizations can offer comparative advantages to address social, economic and political challenges around the world, including social cohesion, empowerment and the recognition of a pluralistic economy. SSE is therefore becoming more important at the present time, given the global economic crisis, when solutions will require, among other aspects, a more inclusive and sustainable development paradigm, as is also expected under environmental participatory governance (Adelle \& Nilsson, 2015; Morais, Dash \& Bacic, 2017). SSE organizations share key features that set them apart from conventional enterprises. They are often bottom-up, have a significant participation of volunteers, who often play an important role in the start-up phase of the organization, consequently, their governance structure also tends to be more inclusive and democratic. This is a new type of community-based development approach through which beneficiaries gain more direct control over project decision-making, implementation and evaluation processes. It supports collective action, community empowerment, and demand-driven local service delivery. These are the seeds for innovative, increasingly self-sustaining local development processes.

There is a wide spectrum of different actors and legal arrangements for SSE in Brazil, however, cooperatives are easiest to find and are the ones with the greatest tradition in the country. Except for the studies on cooperatives, the scientific discussion on SSE is relatively recent (Morais \& Bacic, 2018; 2019). In Brazil, Solidarity Economy (SE) constitutes a mode of production, which differs from capitalism, aspiring for more democratic decision making. According to Paul Singer SE "was created by workers, in the beginning of Industrial Capitalism, as a solution to poverty and unemployment" (Singer, 2002, p. 83). For Singer, the weapon available to those who are deprived of capital is solidarity and SE emerges as reaction to the deprivations that the dominant system refuses to address.

In general terms, the key feature of SSE enterprises is that they produce goods or services with 'social value' and are not eminently guided by profit. Profit (or surplus), however, is essential for the sustainability and development of SSE organizations and enterprises. However, it is not considered as ultimate goal, in addition, it is used and distributed according to the specific rules inherent to the previously agreed and defined legal structures. Profit and productive surplus are necessary for the socio-economic viability of the SSE and are generally used to expand business and improve the human resources and infrastructure of the actors involved. Cooperatives, for example waste picker cooperatives, operate in a capitalist environment and are thus subject to many challenges and constraints. In his classical text Stewart Perry (1978) gave a detailed account of some of the limitations that cooperatives experience, e.g. caused by competitive pressures that affect the organization and that can distract from the original values and principles of the cooperative. Egan (1990) remarks that cooperatives are compelled to operate within the logic of capitalism, producing and selling in the market, "thereby reproducing the commodification of use values [which further] ...forces cooperatives into competition with each other" (p. 72). Our research will demonstrate how particularly waste picker organizations in Brazil are committed to core values and principles of the SSE and have distinguished themselves from many other examples of cooperatives.

TABLE 1: Different definitions, operating principles and forms of the SSE.

\begin{tabular}{|c|c|c|}
\hline Definitions of SSE & SSE Operational Principles & SSE Entities \\
\hline $\begin{array}{l}\text { Third sector } \\
\text { Voluntary sector } \\
\text { Non-profit sector } \\
\text { Philanthropic sector } \\
\text { Charitable sector } \\
\text { Non-governmental organizations (NGO) } \\
\text { Intermediate sector } \\
\text { Tax-free sector } \\
\text { Social economy } \\
\text { Solidarity economy } \\
\text { Social and solidarity economy } \\
\text { People's economy } \\
\text { Associative movements } \\
\text { Civil society movements } \\
\text { Community economic development } \\
\text { Social innovation } \\
\text { Collaborative economy } \\
\text { Corporate social responsibility } \\
\text { Corporate citizenship } \\
\text { Circular economy } \\
\text { Common good economy }\end{array}$ & $\begin{array}{l}\text { Social value } \\
\text { Fair trade } \\
\text { Responsible and conscious consumption } \\
\text { Democratic and popular management } \\
\text { Social, political and gender empowerment } \\
\text { Local development } \\
\text { Production with social, political and economic } \\
\text { impacts of communities } \\
\text { Collectivity } \\
\text { Reciprocity } \\
\text { Mix of market and non-market resources } \\
\text { Social, political, economic and cultural transfor- } \\
\text { mation of territories } \\
\text { Social cohesion } \\
\text { Popular economy }\end{array}$ & $\begin{array}{l}\text { Cooperatives } \\
\text { Mutual benefit societies } \\
\text { Associations } \\
\text { Foundations } \\
\text { Social enterprises } \\
\text { Recovered factories } \\
\text { Community banks } \\
\text { Exchange clubs } \\
\text { Solidarity economic enterprises }\end{array}$ \\
\hline
\end{tabular}


According to a broad international debate that takes place, within the International Labor Organization (ILO) and involves international SSE scholars and institutes (Borzaga, Salvatori \& Bodini, 2017) we can affirm that:

a) SSE refers to specific forms of organizations and companies, with the most common types being cooperatives, mutual societies, associations, community organizations, social enterprises, foundations, Non-Governmental Organizations (NGOs), solidarity economy enterprises etc. It is, therefore, a group of dynamic and evolving organizations;

b) SSE organizations have common characteristics that differentiate them from public economy and traditional private economy organizations, as they share specific operating principles based on voluntary participation, solidarity, reciprocity, innovation, collective ownership and self-management;

c) The existing range of names that cover the SSE are divergent but yet related concepts. They all have certain geographical origins and theoretical backgrounds that emphasize particular dimensions of this economic form;

d) SSE organizations can offer comparative advantages to address social, economic and political challenges around the world, including social cohesion, 'empowerment' and the recognition of a plural economy;

e) Despite their diversity and heterogeneity, SSE has other fundamental characteristics that differentiate them from traditional companies, such as the fact that their organizations, in large part, are conceived within local communities in response to common opportunities or needs, as well as greater inclusion and democracy in its governance and decision-making processes;

f) SSE is, therefore, acquiring more importance at the present moment, in view of the global economic crisis, since the solutions will require, among other aspects, a more inclusive and sustainable development model.

In general, SSE can be defined as "a concept that refers to enterprises and organizations, in particular cooperatives, mutual benefit societies, associations, foundations and social enterprises, which specifically produce goods, services and knowledge while pursuing economic and social aims and fostering solidarity" (ILO, 2011, cited by Borzaga, Salvatori \& Bodini, 2017, p. 14).

Greater multi-stakeholder participation in governance is a goal in environmental governance which can be facilitated under the SSE and depends on the synergies between governments and different government levels as well as between civil society organizations (UN Environment, 2019). We will further discuss the proposed approach to waste governance in the context of the MRSP. The next section examines waste picker organizations and networks, supported by the SSE and their impact on waste governance.

\section{METHODOLOGY}

Our research uses a qualitative approach, involving document analysis, in-depth key informant interviews and participatory observation. The initial stage involved the search and review of relevant literature on waste governance and the social and solidarity economy, with emphasis on lower income countries. Data collection happened between September and November 2018 and entailed semi-structured, in-depth interviews including both closed- and open-ended questions, involving six waste picker networks operating in the metropolitan region of São Paulo, as well as the National Waste Picker movement (Movimento Nacional de Catadores(as) de Materiais Recicláveis, MNCR). We chose this particular region for our case study because of our longterm trusted relationships with some of the waste picker organizations. Another reason was to explore the large diversity of different working situations among organized waste pickers in the MRSP, where we highly organized and well-equipped groups but also small-scale and precarious organizations.

All interviews were either held in the administrative unit of the network or cooperative. The interviews took between 2 and 3 hours on average. They were taped and later transcribed by the local research assistant (Solange Dias), who was also present during all interviews.

Except for one interview (Catasampa) which was conducted with just one representative of the network, several other members of the network always joined our conversations. The semi-structured interviews were designed to develop a deep understanding of the complex issues that surround the networks, and followed themes that captured the history of the network, their geographic and thematic scope, objectives and governance structure, as well as information related to the social innovations driven by the network. The interviews were manually theme coded to capture key ideas. Interview methodologies, however, do have their drawbacks, as the perspectives and experiences of individuals are not always accurate representations of actions or facts (Knox-Hayes, 2008). Rigour and credibility, therefore, were enhanced through the triangulation of our results across all interviews. The information was compared and complemented with a wide array of document sources (reports, academic papers, website information). The researchers have obtained approval from the University of Victoria Human Research Ethics Council for this project (Protocol \# 17.193).

\section{RESEARCH CONTEXT AND RESULTS}

\subsection{Waste picker organizations in Brazil}

Estimates for the number of waste pickers in Brazil vary between 400,000 and 600,000 , depending on the source (IPEA, 2013). The 2010 official census (IBGE, 2012) provides a number of 387,910 self-declared waste pickers. According to the census, almost 39 per cent were organized in associations, cooperatives or networks. 31 per cent of all waste pickers were female, however, women were the majority of organized waste pickers. The average age of waste pickers were 39 years, most of them were Afro-descendent (66 per cent) and a significant number (20 per cent) was still considered illiterate. Only 25 per cent of all waste pickers have completed their basic education (IBGE, 2012). Currently there are six networks and 95 organized groups in the metropolitan region of São Paulo (verbal 
communication MNCR, 2019).

Many waste pickers are part of the National Waste Pickers' Movement (MNCR), their main political voice, providing new formulations on waste management, disrupting existing assumptions and preconceived ideas about waste pickers. The MNCR was created in 2001, with the goal to expand inclusive solid waste management programs throughout the country and to integrate the struggle of waste pickers for self-determination and inclusion in the praxis of handling solid waste, which also means better access to funding and credit lines. The MNCR is also a member of the Latin American recyclers' movement (RedLacre) and the global network of waste picker organizations (GlobalRec).

In Brazil, the SSE has been instrumental in the formation of solidarity networks of waste picker enterprises, a recent phenomenon in the literature and in the praxis of waste picker organizations (Mota, 2018). Tirado-Soto and Zamberlan (2013) consider that networks of waste pickers are a strategy that allows them to access credit lines and complementary resources, as well as to improve administrative practices (Boeira, Campos \& Ferreira, 2007), adding value to the recyclable materials (Aquino, Castilho Jr. \& Pires, 2009). Not all waste picker cooperatives comply with the high standards of solidarity principles, their leadership might not be democratically established or they might not follow the rules established by the members of the cooperative (e.g. regular meetings, democratic election, etc.) and they are known as 'false cooperatives' among the waste pickers.

Waste picker cooperatives are not immune to the contradictions evident in the capitalist environment under which they have to operate. They struggle to make their decision-making processes democratic and transparent, in line with the values and principles of the SSE. While we also agree with Millar (2018) that formalisation not automatically implies a transition from a precarious to a secure workplace, and that many of the vulnerabilities and insecurities still persist in the cooperative environment, our research results emphasise the opportunities for emancipation and inclusion created through the organization of the waste pickers, through their cooperatives, networks and the social movement. There are different forms of formalization and 'inclusion', which do not comply with these standards (e.g. forced creation of cooperatives or associations after landfill closure) (Millar, 2018). In this article we refer to the 'cooperative model', which is based on autonomy of the workers and inspired by solidarity and cooperation. Other models of formalization might not be built on the same foundation and the risk is high that by merely transferring waste pickers into recycling plants, as a form of social inclusion, the paternalistic social state is just rearranged, as described by Hare (2019) for the case of waste pickers in Uruguay. We do not want to romanticize or idealize workers owned cooperatives and we recognize the many contradictions, challenges and conflicts that persist and we agree that "by including just a small part of the informal labour force, state initiatives [.....] risk re-enacting centuries-old forms of dispossession that rest on the fracturing and partial delegitimization of the working class" (Hare, 2019, p. 43).

\subsection{Waste picker cooperative networks in the metro- politan region of São Paulo}

This section presents the results from the in-depth interviews with leaders of six waste picker networks and the National Movement providing insights to their history, current situation and struggles.

Table 2 provides information about the networks participating in the study (Table 2). The first waste picker network in Brazil was Cataunidos, established in Belo Horizonte/Minas Gerais, in 2002 (Rutkowski, 2013). Out of the 6 networks participating in our study, Rede CATASAMPA was the first to be created in 2006, serving as an example for many of the other networks that followed in the region. COOPCENT ABC was the second network to become formally established in 2008. The other networks that took part in our research were formalized after 2012. The largest network is Rede Paulista, with 41 members and Rede CATASAMPA, with 20 members, while the others have between 7 (COOPCENT ABC) and 15 members (FEPACORE).

All networks revealed that their main objective for creating a network was collective commercialization, which would allow them to sell directly to the industry and get better prices. Collective commercialization at Rede Solidaria Catavida, e.g. happens in the following way: the cooperatives that are members call when they have a freight ready. Then the network collects the materials with their truck and centralizes in their storage space. With sufficient quantity the industry sends a truck to pick up the materials. All interviewees further listed many other reasons for forming a network, listed in Table 3.

Networks, such as Rede CATASAMPA, provide assistance to other cooperatives that are not yet well organized and still work under precarious conditions, helping them solve issues related to work space, lack of infrastructure, or precarious working conditions. Furthermore, as networks they are more respected, able to engage in public policy formulating and have bargaining power to negotiate contracts with their local governments. Sometimes even geographically distant groups are included in a network, demonstrating shared affinities and visions among these groups (Figure 1).

Mota (2018) has studied three waste picker networks in the state of São Paulo and also concluded that networks are generally born with a commercial focus and then evolve towards other purposes and benefits. Starting collaborations with a commercial focus seems to facilitate the consolidation of these groups. The relations between middle men and waste pickers in the Brazilian context are mostly of dependency, subjugation and exploitation. Pádua Bosi (2015) describes how waste pickers in Brazil have week bargaining power and are systematically exploited by the middlemen (atravessadores). Waste pickers frequently comment that they are cheated when it comes to weighting their materials and sometimes the middlemen even fix their scales to register a lower weight (Medina, 2007). Very differently, in the case of India middleman have been reported as important intermediaries, offering a kind of a safety net to waste pickers and also supporting their strive for recognition (Gill, 2010). 
TABLE 2: Networks participating in the research.

\begin{tabular}{|c|c|c|c|c|c|}
\hline Name of the network & Mandate & Geographic region & Affiliated groups & Waste pickers & Date of creation \\
\hline Rede Paulistana & $\begin{array}{l}\text { Commercialization for } \\
\text { the two mega-recycling } \\
\text { centers (megacen- } \\
\text { trais). }\end{array}$ & $\begin{array}{l}\text { Municipality of São } \\
\text { Paulo }\end{array}$ & 41 & 1200 & 2016 \\
\hline $\begin{array}{l}\text { Rede Solidária Ca- } \\
\text { ta-Vida }\end{array}$ & $\begin{array}{l}\text { Collective commer- } \\
\text { cialization. Solidarity } \\
\text { networking. }\end{array}$ & Southwest of RMSP & 14 & 800 & 2001 \\
\hline Rede Sul & $\begin{array}{l}\text { Collective commer- } \\
\text { cialization. Improve } \\
\text { recycling quality. } \\
\text { Support cooperativers } \\
\text { in administrative, tech- } \\
\text { nical and legal issues. }\end{array}$ & $\begin{array}{l}\text { South of MRSP and } \\
\text { Campinas }\end{array}$ & 13 & 800 & 2012 \\
\hline Rede Catasampa & $\begin{array}{l}\text { Collective commer- } \\
\text { cialization. Capacity } \\
\text { building, Collective } \\
\text { purchasing, service } \\
\text { contracts. }\end{array}$ & $\begin{array}{l}11 \text { municipalities } \\
\text { (Guarulhos, São } \\
\text { Paulo, Southern coast } \\
\text { (Santos, Itanhaem, } \\
\text { Mongagua) }\end{array}$ & 20 & 750 & 2006 \\
\hline Coopcent & $\begin{array}{l}\text { Collective commer- } \\
\text { cialization. Political } \\
\text { organization of the } \\
\text { member groups. }\end{array}$ & $\mathrm{ABC}$ region & 7 & 208 & 2008 \\
\hline Fepacore & $\begin{array}{l}\text { Professionalization of } \\
\text { the waste pickers and } \\
\text { collective commercial- } \\
\text { ization. }\end{array}$ & State of São Paulo & 15 & 670 & 2013 \\
\hline \multirow[t]{2}{*}{$\begin{array}{l}\text { Rede Verde Suste- } \\
\text { ntável }\end{array}$} & $\begin{array}{l}\text { Collective commer- } \\
\text { cialization. Capacity } \\
\text { building. }\end{array}$ & $\begin{array}{l}\text { Santana de Parnaiba, } \\
\text { Itapevi, Cotia, Taboão } \\
\text { da Serra, Embu das } \\
\text { Artes, Osasco, São } \\
\text { Paulo }\end{array}$ & 10 & 500 & 2007 \\
\hline & & TOTAL & 120 & 4928 & \\
\hline MNCR & $\begin{array}{l}\text { Political organization } \\
\text { of the member groups. } \\
\text { Professionalization of } \\
\text { waste pickers. Capac- } \\
\text { ity building. Participa- } \\
\text { tion in policy making }\end{array}$ & National level & n.a. & n.a. & 2001 \\
\hline
\end{tabular}

Networks are configured as an important organizational arrangement in the face of the complex challenges presented by the recycling market. All networks had benefited from federal government funding through the Cataforte program, promoted by SENAES, the National Secretariat of Solidarity Economy (Secretaria Nacional de Economia Solidária) and destined for the socioeconomic inclusion of waste pickers. This program was incorporated in the National Development Plan PPA 2012-2015, under the the- matic program 'Number 2067' on Solid Waste, and was instrumental in the rise of waste pickers. Fundação Banco do Brasil, a foundation linked to Bank of Brazil, was another important funding source, mentioned by the networks, to support many actions required for the socio-productive inclusion of waste pickers.

Several networks had initiated or promoted social and technical innovations among their member cooperatives. The network Rede Solidária CataVida, e.g. has set up a

TABLE 3: Waste picker organizations and networks.

\begin{tabular}{|c|c|}
\hline \multicolumn{2}{|c|}{ Major benefits from creating a network } \\
\hline \multirow[t]{4}{*}{ Skill development } & Cooperative administration skills \\
\hline & Workers health and safety \\
\hline & Public policy and waste management \\
\hline & Challenges in material recycling (quality standards, minimizing the waste of resources, new materials) \\
\hline Gender specific aspects & Generating gender awareness \\
\hline Project development & Developing joint funding applications \\
\hline Community outreach & Environmental education interventions \\
\hline $\begin{array}{l}\text { Knowledge exchange among waste } \\
\text { pickers }\end{array}$ & Pricing, conflict resolution, legal compliances \\
\hline Consultancy & Contracts with local governments, business and industry \\
\hline
\end{tabular}




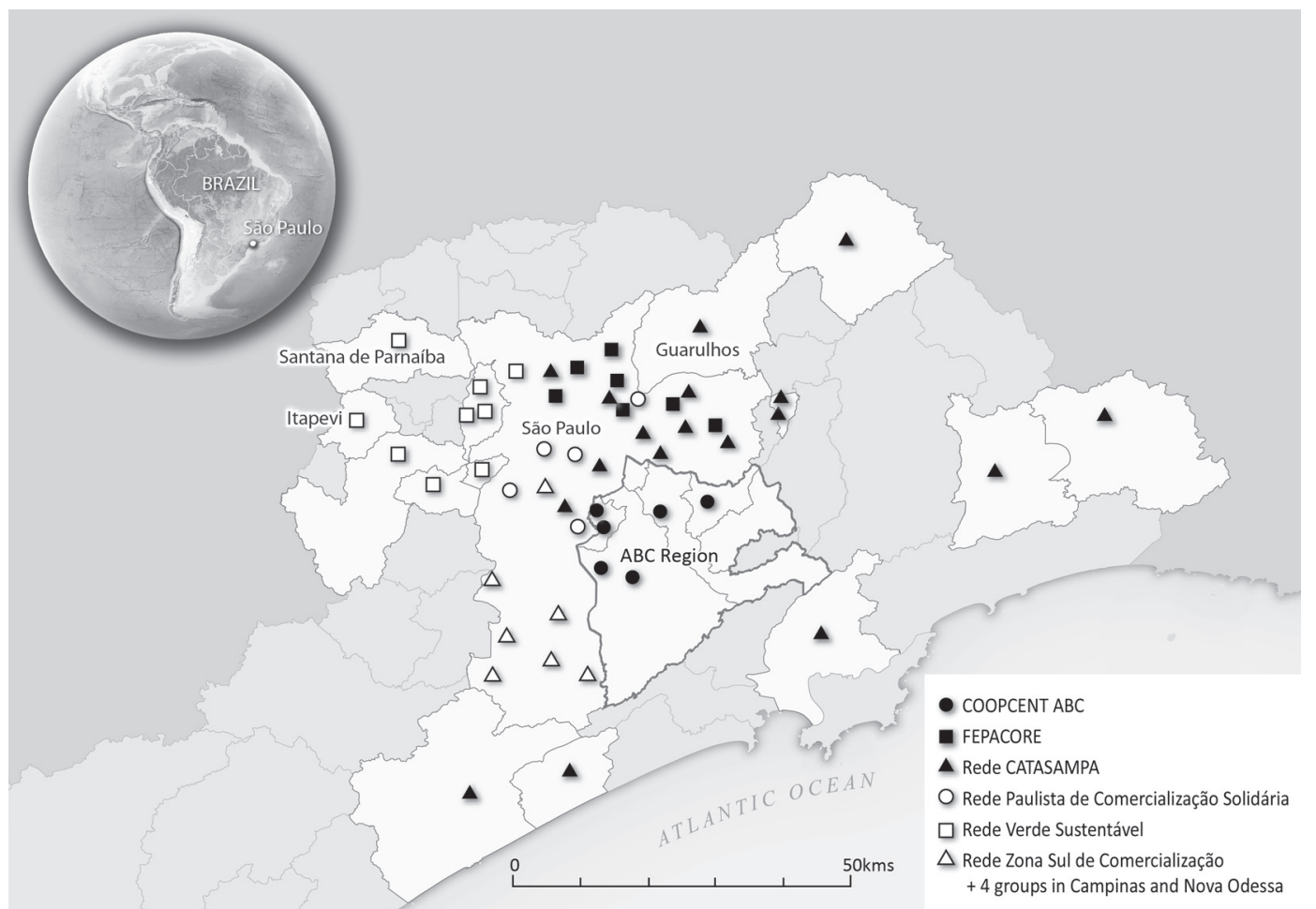

FIGURE 1: Networks participating in the research.

Polymer factory for plastic recycling and has adapted a process to transform cooking oil into soap and animal feed; benefiting all members of the network. Their leader reiterated the importance of waste pickers in adding value and not just collecting and separating materials. Yet, they mentioned that it is difficult to convince all members to invest in making products of higher value. We were told that occasionally cooperatives had left the network because they still preferred to sell to middlemen for a lower price, however receive the payment immediately. The interviews revealed that a downside of collective commercialization is that it can take up to 15 days to receive payment and not all cooperatives have enough cashflow to survive this waiting period.

Nevertheless, collective approaches to commercialization can improve earnings significantly. Rede Solidária CataVida for example sells white High-Density Polyethylene (PEHD) at R\$ 1.80 to the industry, while middlemen are paying only R\$ 0.50 to $\mathrm{R} \$ 0.80$. The largest challenges currently are the lack of recyclable materials, linked to increased competition from new small to medium-scale recycling industries (not waste picker cooperatives). Another bottleneck is the lack of working capital to be able to pay the cooperatives immediately for their materials contributed to collective commercialization (as briefly highlighted before).

Rede CATASAMPA provides public and private collection services, issuing records (certificados) based on the invoices received from the industry who purchases their sorted materials. In Mogi das Cruzes, Rede CATASAMPA services the municipal recycling program, Reciclamogi. The program survived the change in local government, demonstrating resilience and the ability of the network to provide high quality service. The waste pickers involved in the program receive a fixed value for collection and sorting, based on operational costs. The workers benefit from subsidized transportation, food, health coverage, holidays and paid annual leave. Their monthly income is approximately 1 minimum salary (R\$ 1,045 or 209 US\$) plus benefits. The creation of waste picker networks is a recent phenomenon and still lacks research. Our study confirms that networks are created to support and further consolidate waste picker cooperatives, providing them with capacity building opportunities, technical, administrative and financial training or services and facilitating collective commercialization to increase their income (Tirado-Soto \& Zamberlan, 2013). Network leaders revealed that their networks support the cooperative members during contract negotiations with the city or with industry partners, strengthening their position. The network also just helps disseminate relevant information to the cooperatives (e.g. related to new legislation, price developments, capacity building and funding opportunities, etc.).

The literature shows that cooperatives involved in collective commercialization are better equipped for the challenges of the recycling market (Pisano et al., 2019). In addition, our research highlights that network articulation is not limited to providing a direct economic benefit. Bringing cooperatives together as a network has the potential to strengthen the social assets of the cooperatives, empowering them politically and economically, be it by selling directly to the industry, by providing services or capacity building activities, by exchanging their experiences and knowledge among each other, or by helping in the negotiation of contracts with local governments. 
Waste picker networks are important organizations to deal with new challenges. These challenges are e.g. related to the volatile global recycling market and fluctuating prices, or the emergence of new materials, for which there is no market. The interviewees also recorded growing competition over recycling, with new entrepreneurs (not guided by SSE principles) arriving in this previously undervalued market and they recognized that organizing is critical for waste pickers to be able to participate in reverse logistics. According to the network leaders we interviewed, some cooperatives were facing internal management hurdles and also financial difficulties related to accumulated debts from unpaid fines, which puts them at risk of losing the agreement with the city hall. Many groups are not able to comply with the legislation and get fined for that. The leaders mentioned that the cooperatives always need to demonstrate to a city hall or company that they are competent and able to do the service. Sometimes, political change interrupts the pay for the collection service, leaving the waste pickers with lower income. There still seems to prevail a strong stigma against waste pickers among local government and continuous dialogue with Government is needed, to overcome prejudice and marginalization. Networks also mentioned that they are often understaffed to assist in policy making. However, they all reiterated the necessity for waste pickers to work together and find consensus, which will then strengthen the cooperatives. Some interviewees also were concerned with increasing the number of cooperatives affiliated to the network, to increase the collective power.

\section{DISCUSSION: PARTICIPATORY WASTE GOVERNANCE IN THE METROPOLITAN RE- GION OF SÃO PAULO}

The period of more inclusive waste governance and supportive public policies, in Brazil, coincides with the governments of President Luiz Inácio Lula da Silva (2003 to
2011) and President Dilma Rousseff (2011 to 2016). Since 2002, the profession waste picker (catador) has become legal. Several additional laws have been enacted since, in support of inclusive solid waste management and decent working conditions for waste pickers. Table 4 summarizes some of the public policies and actions, instrumental in changing the working conditions and creating opportunities for cooperatives to be included in the recycling chain.

One of the key driving forces for the socio-economic inclusion of waste pickers was the creation of the federal agency for Solidarity Economy (SENAES), in 2003, under the Ministry of Work and Employment. At the same time the Brazilian Forum of Solidarity Economy (Fórum Brasileiro de Economia Solidária, FBES) was constituted, with the objective to articulate and mobilize SE and to maintain a direct communication channel with SENAES. Since 2008, SENAES has narrowed the relations with MNCR, which allowed organized waste pickers to capture funding for infrastructure and education. Programs such as the Urban Solid Waste Program (Programa Resíduos Sólidos Urbanos) have helped organize waste pickers and have given them more visibility. In 2010, SENAES created the Pro-Catador program to integrate and coordinate the actions of the federal government supporting waste picker organizations, with actions to improve working conditions and expand selective waste collection, reuse and recycling through the inclusion of waste pickers. The fact that the federal law includes solid waste as part of sanitation has furthermore extended funding opportunities for this sector.

The 2010 Brazilian National Waste Management Legislation (PNRS) emphasizes selective waste collection and recycling and requires municipalities to integrate organized waste pickers (Besen \& Fracalanza, 2016; Gutberlet, 2018). The PNRS has established several targets for the reduction of waste disposal at landfills, by 2014 (Brazil, 2010; Tavares Campos, 2014), most of these targets have not yet been met. In 2018, the formal material recovery rate from

TABLE 4: Brazilian Legislation supporting waste pickers activities.

\begin{tabular}{|c|c|}
\hline Law/Decree/Action & Main objectives \\
\hline Federal Law No. 5,764 of December 1971 & Establishes the National Policy on Cooperatives \\
\hline $\begin{array}{l}\text { In 2002, the Ministry of Labor and Employment creates the professional } \\
\text { category: catador collector of recyclable materials and includes it in the } \\
\text { Brazilian classification of occupations (CBOS), under the Code 5192-05 } \\
\text { (MTE. Classificação Brasileira de Ocupações) }\end{array}$ & $\begin{array}{l}\text { Legal and formal recognition of the occupation of collector of recyclable } \\
\text { materials, setting parameters for the development of this activity }\end{array}$ \\
\hline Decree No. 5,940, 25 October 2006 & $\begin{array}{l}\text { Requires public institutions to separate and donate the recyclable fraction } \\
\text { of their solid waste to recycling associations and cooperatives }\end{array}$ \\
\hline $\begin{array}{l}\text { Federal Law No. 11,445, of } 5 \text { January 2007: National Policy on Basic } \\
\text { Sanitation }\end{array}$ & $\begin{array}{l}\text { Authorizes the municipalities to hire recycling associations and coopera- } \\
\text { tives to collect, process and market recyclable or reusable municipal solid } \\
\text { waste }\end{array}$ \\
\hline $\begin{array}{l}\text { Federal Law No. 12,017 of August } 2009 \text { and published the annex VII of the } \\
\text { D.O.U, 13.8.2009, extra Edition }\end{array}$ & $\begin{array}{l}\text { Changes the law of the budget guidelines, allowing the direct transfer of re- } \\
\text { sources to cooperatives, without intermediation of municipalities or social } \\
\text { organizations of public interest }\end{array}$ \\
\hline $\begin{array}{l}\text { Federal Law No. 12,305, July } 2010 \text { and its regulation through Decree No. } \\
\text { 7,404 of December } 2010\end{array}$ & $\begin{array}{l}\text { Establishes the National Solid Waste Policy and creates the Inter-ministeri- } \\
\text { al Committee of the Brazilian solid waste Policy and the Steering Commit- } \\
\text { tee for the implementation of the reverse logistics systems }\end{array}$ \\
\hline $\begin{array}{l}\text { Federal Decree No. 7,405, } 23 \text { December 2010, published in D.O.U. of } 23 \\
\text { December } 2010\end{array}$ & $\begin{array}{l}\text { Institutes the Pro-Catador program. It creates the joint inter-ministerial } \\
\text { Committee for social and economic inclusion of the collectors of reusable } \\
\text { and recyclable material }\end{array}$ \\
\hline Federal Law No. 12,690, of 19 July 2012 published in D.O.U., 20 July 2012 & Rules on the organization and functioning of Workers' Cooperatives \\
\hline
\end{tabular}


municipal selective waste collection programs in Brazil is estimated at 7.3 per cent of dry, recyclable household waste (Brazil, 2019). All formal programs rely mostly on the integration of waste picker organizations. The census identified a total of 27,063 waste pickers working in 1,232 associations or cooperatives, in 827 municipalities. Many waste pickers still operate informally and are often not integrated in local selective waste collection programs.

In 2018, 38.1 per cent of the 3,468 Brazilian municipalities that had participated in the survey (Brazil has a total of 5,570 municipalities) claimed to have a municipal selective collection system in place, with different levels of coverage (Brazil, 2019). With the advent of increased pressure to close landfills and quickly solve the surmounting problem of solid waste accumulation, public private partnership (PPP) funding waste incineration and waste-to-energy has recently risen as a new threat to the livelihoods of waste pickers (Rodrigues, Azevedo \& Gutberlet, 2015; Gutberlet, Bramryd \& Johannson, 2020).

The challenge of reducing the generation of waste and of managing the over 180,000 tons of municipal waste that are produced on the national level, every day in Brazil, requires integrated public policies that are articulated between the main actors and involve efficient management systems that incorporate transparency and accountability geared towards building co-responsibility among citizens and other waste generators (Reis, Conti \& Correa; 2015; Jacobi \& Besen, 2017). The following figure (Fig. 2) shows the diversity of possible actors involved in waste management.

Dias and Samson (2016) showcase some experiences of transformative modes of waste governance in various cities in Brazil. The research demonstrates how important government funding (grants, microcredit) is, acting as a cushion to fall back on, particularly during times of instability and low income. The study shows how the lack of such programmes increases the vulnerability of waste pickers. The authors also identified main factors that support waste pickers in different contexts of formal integration into solid waste management, as well as, the various roles all levels of government play in inclusive waste management.

The discussion on public policies unveils gains and setbacks and refers to the necessary adaptation of the political actors to constantly changing situations. In some cities, such as Belo Horizonte, the formal integration of waste pickers has persevered over a long period of time (21 years), which according to Dias and Samson (2016) is mainly due to two factors: 1) the power of the organizing process in the city (most member-based organizations are active participants in the national movement of waste pickers and also participate in several socio-governmental platforms), and 2) the commitment of dedicated officers at the municipal sanitation agency who pressure the mayor's office to continue with inclusive solid waste management policies. Often these programs do not survive in the absence of local government support and the political will of decision makers.

Diadema, in the MRSP, was the first municipality to create, in 2005, a law that establishes remuneration for the service provided by waste pickers (municipal law 2.336/2004 and Decree 5.984/2005). However, this municipal law is currently not respected given the lack of political will of the current government and the weak participatory governance structures (Jacobi \& Besen, 2011; Gutberlet, 2015). Waste pickers have been continuously demanding for the implementation of the law but without success. Other cities, like Ribeirão Pires, São Caetano do Sul, Guarulhos and Mauá in the metropolitan region of São Paulo as well as Ourinhos, Ribeirão Preto in the interior of São Paulo have implemented and maintained their service payments. The city of Ribeirão Pires pays R\$ 527 (US\$ 105) per ton of separated material to Cooperpires and Ourinhos pays R\$746 (US\$ 149) per ton to the cooperative Mãos Dados. In both cases the networks (Coopcent-ABC in the case of Ribeirão Pires and Rede Anastasia in the case of Ourinhos)

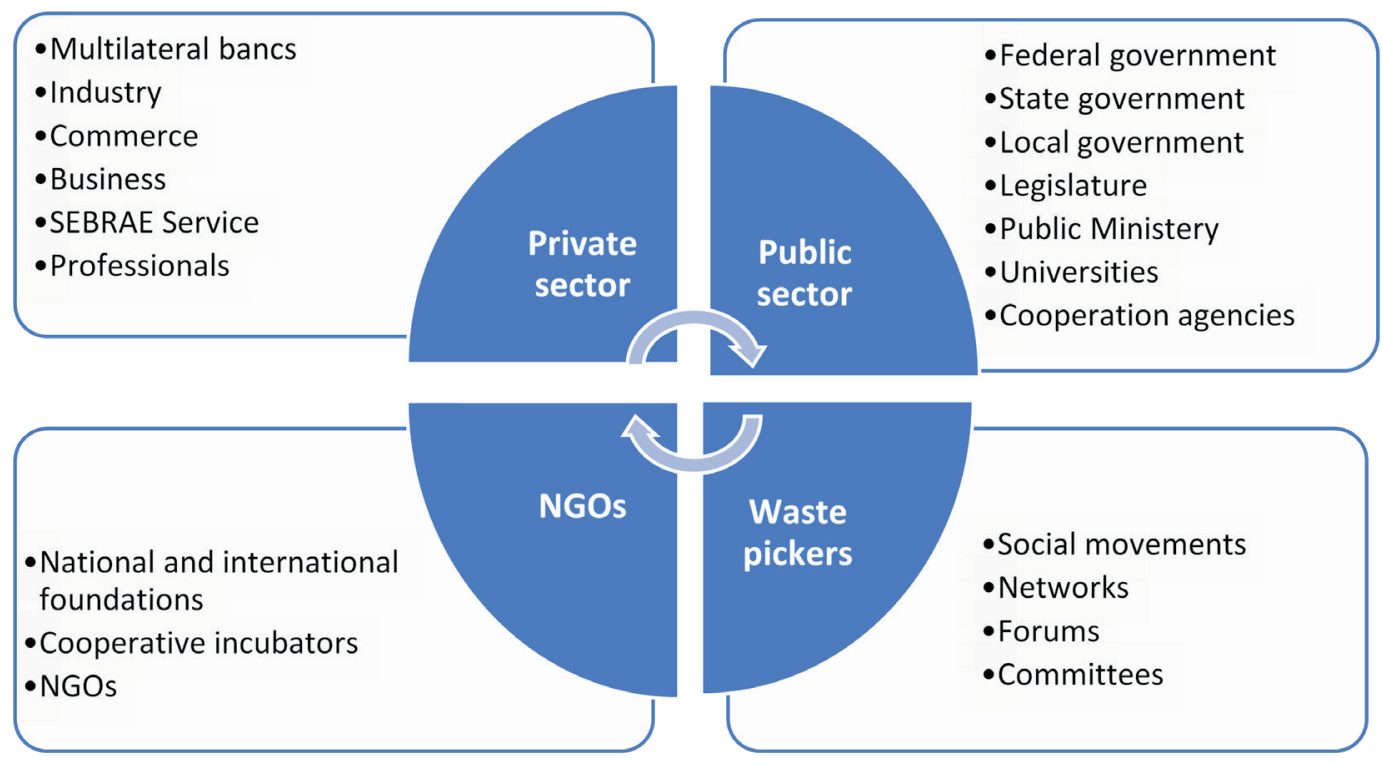

FIGURE 2: Actors involved in the socio-productive inclusion of waste pickers. 
were instrumental in the negotiation between the cooperative and the municipality, establishing these contracts. Similar ideas are tested out by municipal governments in Bolivia, Argentina and Colombia, with moving towards the integration of waste pickers and the payment for separate waste collection and recycling services (Tavares Campos, 2014; Murakami et al., 2015; Rutkowski \& Rutkowsky, 2015; Gutberlet, 2016). The monetary service recognition makes a significant difference in the income of the waste pickers.

The research has helped understand the role of collective commercialization as important starting point for better articulation between waste picker organizations and local governments, as also described by other authors (Azevedo et al., 2018; Pisano et al., 2019). Collective commercialization is a concrete and tangible goal opening the dialogue among the groups; however, there needs to be enough cash flow to immediately pay the cooperatives for their work. Those networks that have succeeded today economically have also been able to diversify their benefits, supporting them in their relations with government and industry. Our results show that expanding the political role of waste pickers through networking is important to promote inclusive environmental waste governance. Our examples demonstrate how essential the support provided by the SSE is, allocating funds to waste pickers to better equip them with knowledge and infrastructure.

Some of these tangible socio-economic advancements of the SSE and participatory governance in Brazil are challenged by recent changes in the federal government. With President Temer, between 2016 and 2018, the National Secretariat for Solidarity Economy (SENAES) was reduced to a Sub-secretariat in the Ministry of Labour, receiving significantly less funding, thus restricting the scope and action of the SSE. The gradual dismantling of SENAES further continued with the present government (Bolsonaro) extinguishing the Ministry of Labour and SENAES. The SSE in Brazil has now become a 'directory board', allocated within the recently created Ministry of Citizenship (provisional measure 870/2019). This new structure expresses both the extinction of SENAES and the changes in policies, associating the SSE with the policies of social assistance and not any more with 'productive inclusion'. The withdrawal of the state from SSE has weakened the process of socioeconomic inclusion of vulnerable actors, such as the waste pickers. The advances detected in our empirical study are on verge of being lost, due to the recent changes in federal waste governance, marked by authoritarian, top-down decision-making and the dismantling of inclusive and participatory governance structures, including the SSE.

\section{CONCLUSIONS}

Waste progressively gains more attention among scholars and policy makers, and new actors and organizations have emerged over time. This article introduces a case study involving several waste picker networks located in the Metropolitan Region of São Paulo and analyses the cases where a collective approach to waste management has changed waste governance.

Social and technological innovations since the late 1990s have introduced important changes to waste governance in Brazil, and new ways of organizing waste pickers into cooperatives, associations and networks, allowing for new models in waste governance to evolve. The emergence of large numbers of waste picker organizations and networks is also linked to the expansion of the Social and Solidarity Economy in Brazil, since the early 2000s. SSE allows for diverse socioeconomic practices to emerge, generating jobs and opportunities for practicing democracy. Similar levels of organization are also developing in other countries in Latin America, in Asia and in Africa in particular.

SSE proves to be a viable development model as there are currently about 21 thousand solidarity economy enterprises in Brazil, involving more than 1.5 million members, of which almost 7 thousand are cooperatives operating in 13 branches of activity, with 14, 6 million members (OIBESCOOP, 2019). Approximately 10 per cent $(40$ to 60,000$)$ of all waste pickers in Brazil are organized and are members in cooperatives and associations, making up a total of 1,100 waste picker organizations in the country (Brazil, 2011). Many have organized as networks, allowing them to collectively sell their materials and to coordinate other actions that enhance their capacity in waste management. Based on this development model, the objective of the cooperative is to generate work, income and to improve the working and living conditions of its members. Waste picker cooperatives are self-managed and practice solidarity, e.g. by including also vulnerable and underprivileged individuals (e.g. suffering from mental or physical health or from addiction problems), who otherwise would not have paid work. Organized waste pickers demonstrate that there is honour in the work they perform and that their workplace democracy has not given in to what Steward E. Perry (1978) has called 'the iron law of oligarchy'.

The Brazilian experience illustrates how a prolonged period of progressive social policy can help built a robust social and solidarity economy, creating unseen opportunities for a sector which was previously excluded. Yet, the example also shows how fragile institutional frames are, depending on who is governing; as we observe with the current political situation, where SSE institutions have suffered neoliberal dismantling. In particular, we understand that these issues also have international parallels, particularly, related to conflicts associated with economic crises, unemployment, environmental challenges and the exacerbation of neoliberal and austerity pressures. In this sense, we believe that there is a significant contribution to the discussion on the role of this type of grassroots social organization in confronting these political forces in a global context, where the level of organization of the waste pickers and the strength of the cooperation with local governments will determine the resistance and persistence of inclusive waste management arrangements.

Particularly since 2010, waste pickers in the MRSP and beyond have begun organizing into networks, signing contracts with city administrations and expanding their activities into co-production of urban services including environmental education and reverse logistics programs. Despite many difficulties and constraints attached to co-production in waste management (particularly due to 
working with vulnerable populations), there are gains for city administrations, communities, the waste pickers and the environment. The obvious gains from waste co-production are (1) social: building more inclusive communities (reducing unemployment providing low barrier jobs, particularly for women and vulnerable individuals) and (2) environmental: contributing to urban sustainability (increasing resource recovery and the circular economy). Innovative experiences and collaborative arrangements as discussed in this paper demonstrate these opportunities and multiple social, economic and environmental benefits for cities and their populations.

The most successful cases of cooperative recycling are those with co-production arrangements, where local governments sign contracts with organized waste pickers to pay for the collection and separation services provided and were reverse logistics programs are in place. Public policies formalizing these inclusive arrangements are crucial to guarantee a successful and lasting programme, but they are not enough. The organization into networks provides the groups with a stronger political voice, pressuring municipalities to include them in waste management. $A$ shift towards integrated, collaborative environmental governance is vital to make the co-produced service work.

We have given examples from the metropolitan region of São Paulo for singular technological innovations and new forms of waste governance involving membership-based waste picker organizations and have shown the relevance and roles of waste picker networks in supporting their members, increasing their income (through collective commercialization but also by supporting local groups to establish service contracts with local governments) and offering experiences to skillfully and successfully run a waste picker cooperative. The Brazilian case highlights how the SSE with waste picker organizations (cooperatives, networks, the National Waste Pickers' Movement) have been able to develop an institutional and policy frame in support of waste pickers. However, we also learn that there are setbacks, specifically tied to prevailing neoliberal political contexts.

\section{REFERENCES}

Adelle, C. \& Nilsson, M. (2015) Environmental Policy Integration. In Encyclopedia of Global Environmental Governance and Politics. In: Pattberg, P., H. and Zelli, F. (eds.). Cheltenham: Edward Elgar. Ch. 58, pp.454-461. Retrieved from: https://www.e-elgar.com/shop/ encyclopedia-of-global-environmental-governance-and-politics

Alvarez, J. F. (2018) Economía social y solidaria en el territorio: significantes y co-construcción de políticas públicas. In: Colección Escuela Javeriana de Gobierno y Ética Pública, (2), Bogota: Pontificia Universidad Javeriana.

Andrews, M. (2008) Good governance means different things in different countries. Faculty research working paper series no. REP08068. John F. Kennedy School of Government, Harvard University. Retrieved from: https://core.ac.uk/reader/6618215.

Aparcana, S. (2017) Approaches to formalization of the informal waste sector into municipal solid waste management systems in lowand middle-income countries: Review of barriers and success factors. Waste Management, 61, 593-607.

Aquino, I. F.; Castilho Jr., A. B. \& Pires, T. S. L. (2009) Organização em rede dos catadores de materiais recicláveis na cadeia produtiva reversa de pós-consumo da região da grande florianópolis: uma alternativa de agregação de valor. Gestão \& Produção, 16 (1), $15-24$.
Asim, M.; Batool, S.A. \& Chaudhry, M.N. (2012) Scavengers and their role in the recycling of waste in Southwestern Lahore. Resources, Conservation and Recycling, 58, 152-162.

Azevedo, A. M. M. de; Carenzo, S.; Goodluck, C.; Gutberlet, J.; Kain, J.H.; Oloko, M. O.; Pérez Reynosa, J.; Zapata, P. \& Zapata Campos, M. J. (2018) Inclusive waste governance and grassroots innovations for social, environmental and economic change: Report on first research outcomes of the project Recycling Networks \& Waste Governance. Swedish Research Council ( $n^{\circ}$ 2016-06289) and Canada Social Sciences and Humanities Research Council ( $n^{\circ}$ 890-2016-0098). In collaboration with WIEGO. ISBN 978-91984547-3-4.Retrieved from: http://www.wiego.org/reports/inclusive-waste-governance-and-grassroots-innovations-social-environmental-and-economic-chan

Besen, G. R.; Ribeiro, H.; Gunther, W. M. R. \& Jacobi, P. R. (2014) Selective waste collection in the São Paulo metropolitan region: impacts of the national solid waste policy. Ambiente \& Sociedade [online], Vol. XVII (3), 253-272. Doi: 10.1590/S1414-753X2014000300015.

Besen, G.R. \& Fracalanza, A.P. (2016) Challenges for the Sustainable Management of Municipal Solid Waste in Brazil. JournaldisP - The Planning Review. 52 (2), 45-52. Doi: 10.1080/02513625.2016.1195583

Binion, E. \& Gutberlet, J. (2012) The effects of handling solid waste on the wellbeing of informal and organized recyclers: A review of the literature. Journal of Occupational and Environmental Health. 18 (1), 43-52.

Boeira, S. L.; Campos, L. M. D. S. \& Ferreira, E. (2007) Redes de catadores- recicladores de resíduos em contextos nacional e local: do gerencialismo instrumental à gestão da complexidade? Organizações \& Sociedade, 14 (43), 37-55.

Borgaza, C.; Salvatori, G. \& Bodini, G. (2017) Social and Solidarity Economy and the Future of Work. Euricse Working Paper for the ILO/ International Labour Office. - Geneva: ILO, 2017.

Brazil (2010) Política Nacional de Resíduos Sólidos Lei n 12.305 02.08.2010. Retrieved from: http://www.planalto.gov.br/ccivil_03/_ato20072010/2010/lei/l12305.htm.

Brazil (2011) Plano Nacional de Resíduos Sólidos. Versão preliminar para consulta pública. Retrieved from: http://www.mma.gov.br/estruturas/253/_publicacao/253_publicacao02022012041757.pdf.

Brazil (2019) Programa de modernização do setor de saneamento: Diagnóstico da gestão e manejo de resíduos sólidos urbanos 2018. Ministério das Cidades. SNIS - Sistema Nacional de Informações sobre Saneamento. Brasília: MCIDADES/ SNSA.

Bryant, R. L. (1998) Power, Knowledge and Political Ecology in the Third World: A Review. Progress in Physical Geography 22 (1), 79-94.

Bulkeley, H.; Watson, M.; Hudson, R. \& Weaver, P. (2005) Governing municipal waste: towards a new analytical framework. J. Environ. Plann. Policy Manage. 7 (1), 1-23. http://dx.doi. org/10.1080/15239080500251700.

Chaturvedi, B. (2009) 'A scrap of decency', The New York Times, NYTimes.com, www.nytimes.com/2009/ 08/05/ opinion/05chaturvedi.html.

Chaves, R. \& Monzón, J. L. (2018) La economía social ante los paradigmas económicos emergentes: innovación social, economía colaborativa, economía circular, responsabilidad social empresarial, economía del bien común, empresa social y economía solidaria. In: CIRIEC-España, Revista de Economía Pública, Social y Cooperativa, 93, 5-50, DOI: 10.7203/CIRIEC-E.93.12901.

Dias, S. \& Samson, M. (2016) Informal Economy Monitoring Study Sector Report: Waste Pickers. Cambridge, MA, USA: WIEGO. Retrieved from: http://www.wiego.org/sites/wiego.org/files/publications/ files/Dias-Samson-IEMS-Waste-Picker-Sector-Report.pdf

Dias, S.M. (2016) Waste pickers and cities. Environment \& Urbanization. 28 (2), 375 - 390. DOI: 10.1177/0956247816657302.

Duan, H., Li, J. \& Liu, G. (2017) Developing countries: Growing threat of urban waste dumps. Nature 546(7660), 599-599. https://doi. org/10.1038/546599b.

Egan, D. (1990). Toward a Marxist Theory of Labor-Managed Firms: Breaking the Degeneration Thesis. Review of Radical Political Economics, 22 (4), 67-86.

Ezeah, C.; Fazakerley, J.A. \& Roberts, C.L. (2013) Emerging Trends in informal sector recycling in developing and Transition countries. Waste Management, 33, 2509-2519.

Ezeah, C., \& Roberts, C. L. (2014) Waste governance agenda in Nigerian cities : A comparative analysis. Habitat International, 41, 121-128. https://doi.org/10.1016/j.habitatint.2013.07.007 
Fei, F., Qu, L., Wen, Z., Xue, Y. \& Zhang, H. (2016) How to integrate the informal recylcing system into municipal solid waste management in developing countries: Based on a China's case in Suzhou urban area. Resources, Conservation and Recycling, 110, 74-86.

Ferri, G. L.; Chaves, G. L. D. \& Ribeiro, G. M. (2015) Reverse logistics network for Municipal solid waste management: The inclusion of waste pickers as a Brazilian legal requirement. Waste Management, 40, 173-191.

Gill, K. (2010). Of Poverty and Plastic. Delhi: Oxford University Press.

Gutberlet, J. (2008) Recycling Citizenship, recovering resources: Urban poverty reduction in Latin America Ashgate, Aldershot, 163 pp.

Gutberlet, J. (2015) Cooperative urban mining in Brazil: Collective practice in selective household waste collection and recycling. Waste Management, 45, 22-33.

Gutberlet, J. (2016) Urban Recycling Cooperatives: Building Resilient Communities. London, New York: Routledge Taylor \& Francis Group. 183 pp.

Gutberlet, J., Bramryd, T., \& Johansson, M. (2020) Expansion of the Waste-Based Commodity Frontier: Insights from Sweden and Brazil. 1-14. https://doi.org/10.3390/su120726280

Gutberlet, J., Kain, J.-H., Nyakinya, B., Oloko, M., Zapata, P., \& Zapata Campos, M. J. (2017) Bridging Weak Links of Solid Waste Management in Informal Settlements. The Journal of Environment \& Development. 26 (1), 106-131. http://doi.org/10.1177/1070496516672263

Gutberlet, J. \& Uddin, S. M. N. (2018) Household waste and health risks affecting waste pickers and the environment in low- and middle-income countries. Int $\mathrm{J}$ of Occupational and Environmental Health. 23(6), 1-12. DOI:10.1080/10773525.2018.1484996. Retrieved from: https://www.tandfonline.com/eprint/qHn7kcvWVAlnlkKYr98c/full

Hare, P. O. (2019) 'The landfill has always borne fruit': precarity , formalisation and dispossession among Uruguay's waste pickers Dialect Anthropol 43, 31-44. https://doi.org/10.1007/s10624-0189533-6.

Heynen, N.; Kaika, M. \& Swyngedouw, E. (eds) (2006) In the Nature of Cities: Urban Political Ecology and the Politics of Urban Metabolism, London: Routledge.

Hoornweg, D. \& Bhada-Tata, P. (2012) What a waste: a global review of solid waste management. Washington DC: World Bank Group. Urban Development Series Knowledge Papers, 98 p. Abel at: http:// goo.gl/XjADqo

IBGE (Instituto Brasileiro de Geografia e Estatística) (2012) Pesquisa Nacional por Amostra de Domicílio 2012. Rio de Janeiro: IBGE.

ILO (International Labor Organization) Green Jobs (2013) Sustainable development, decent work and green Jobs. Report V Geneva. https://www.ilo.org/wcmsp5/groups/public/---ed_norm/---relconf/documents/meetingdocument/wcms_207370.pdf

IPEA (Instituto de Pesquisas Econômicas Aplicadas) (2013) Situação social das catadoras e dos catadores de material reciclável e reutilizável - Brasil. Brasília: IPEA.

IPEA (Instituto de Pesquisas Econômicas Aplicadas) (2016) Os novos dados do mapeamento de economia solidária no Brasil: nota metodológica e análise das dimensões socioestruturais dos empreendimentos. Relatório de Pesquisa. Brasil. Brasília: IPEA

Jacobi, P. R. \& Besen, G. R. (2011) Solid Waste Management in São Paulo: the challenges of sustainability. Estudos Avançados, São Paulo, 25 (71). 135-158. http://dx.doi.org/10.1590/S010340142011000100010.

Jacobi, P. R. \& Besen, G. R. (2017) Política e accountability da gestão de resíduos sólidos no município de São Paulo. In: Mecanismos de accountability en la gestión de residuos sólidos, en Colombia y Brasil Universidad Los Libertadores. Bogotá, D.C., Colombia.

Jaligot, R., Wilson, D.C., Cheeseman, C.R., Shaker, B. \& Stretz, J. (2016) Applying value chain analysis to informal sector recycling: A case study of the Zabaleen. Resources, Conservation and Recycling, $114,80-91$.

Jordan, A. \& Lenschow, A. (2010) Environmental policy integration: A state of the art review. Environmental Policy and Governance 20 (3), 147-158. https://doi.org/10.1002/eet.539.

Kaza, S.; Yao, L.; Bhada-Tata, P. \& Van Woerden, F. (2018) What a Waste 2.0. A global snapshot of solid waste management to 2050. Urban Development Series. World Bank Group. Retrieved from: https:// openknowledge.worldbank.org/handle/10986/2174

Leite, M. P. (2011) Cooperativas e trabalho: um olhar sobre o setor de reciclagem e fábricas recuperadas em São Paulo. Faculdade de Educação e Doutorado em Ciências Sociais/UNICAMP, Campinas/
Lemos, M. C., \& Agrawal, A. (2014) Environmental Governance. (January 2008). https://doi.org/10.1146/annurevenergy.31.042605.135621.

Linzner, R. \& Lange, U. (2013) Role and size of the informal sectors in waste management- a review. Proceedings of the Institution of Civil Engineers - Waste and Resource Management, 166 (2), 69-83. https://doi.org/10.1680/warm.12.00012.

Medina, M. (2000) Scavenger cooperatives in Asia and Latin America. Resources, Conservation and Recycling; 31(1), 51-69.

Medina, M. (2007) The world's scavengers: Salvaging for sustainable consumption and production. Plymouth: AltaMira Press.

Millar, K. M. (2018) Reclaiming the Discarded: Life and Labor on Rio's Garbage Dump. Duke University Press.

Moore, S. A. (2012) Garbage matters: concepts in new geographies of waste. Progress in Human Geography 36 (6), 780-799.

http://dx.doi.org/10.1177/0309132512437077.

Morais, L. (2013) As políticas públicas de Economia Solidária (ESOL) avanços e limites para a inserção sociolaboral dos grupos-problema. Campinas: IE-UNICAMP (PhD thesis).

Morais, L. (2014) Cooperação Sul-Sul e triangular e Economia Social Solidaria: possíveis conexões e contribuições para o desenvolvimento sustentável inclusivo. Retrieved from: http://www.ilo.org/ wcmsp5/groups/public/---dgreports/---exrel/documents/genericdocument/wcms_236661.pdf

Morais, L. \& Bacic, M. (2018) Modern cooperatives in the system of sustainable development goals: the importance of the solidarity entrepreneurship ecosystem, in Journal Fundamental applied researches of coop sector of economics. Moscow, December no. 6, 20-37

Morais, L.; Dash, A. \& Bacic, M. (2017) Social and solidarity economics in India and Brazil, In: Social Enterprise Journal. Retrieved from: https://www.emerald.com/insight/content/doi/10.1108/SEJ-072016-0035/full/html

Morais, L.\& Bacic, M. A (2019) Importância do ecossistema empreendedor para a Economia Social e Solidária (ESS): avanços, retrocessos e desafios atuais no Brasil, Revista da ABET (Associação Brasileira de Estudos do Trabalho), 18 (1), 3-21. Retrieved from: http:// www.periodicos.ufpb.br/index.php/abet/article/view/38568.

Moreno, A. S. (1996) Análisis económico del sector no lucrativo. València: Ed. Tirant lo Blanch Libros, Valencia.

Motta, V. P. (2017) Dinâmicas de cooperação e a sustentabilidade das redes de cooperativas de catadores de materiais recicláveis: estudo de casos múltiplos.174 f. Dissertação (Mestrado em Administração) - Centro Universitário FEI.

Moulaert, F, \& Ailenei, O. (2005) Social economy, third sector and solidarity relations: A conceptual synthesis from history to present. Urban Studies, 42(11), 2037-2054. https://doi. org/10.1080/00420980500279794

Moulaert, F. \& Nussbaumer, J. (2005) Defining the Social Economy and its Governance at the Neighbourhood Level: A Methodological Reflection. 42(11), 2071-2088.

Murakami, F.; Sulzbach, A.; Medeiros Pereira, G.; Borchardt, M. \& Sellitto, M. A. (2015) How the Brazilian government can use public policies to induce recycling and still save money? Journal of Cleaner Production 96, 94-101.

OIBESCOOP. Anuário Ibero Americano de la Economía Social. Valéncia: Ed. CIRIEC España. 2019. Retrieved from: http://www.oibescoop. org/wp-content/uploads/Anuario_Iberoamericano_OIBESCOOP_ n3_2018.pdf

ONUBR (Naçōes Unidas Brasil) (2015) 17 Objetivos para transformar nosso mundo. Retrieved from: https://nacoesunidas.org/ pos2015/agenda2030/

Otsukia, K. (2016) Infrastructure in informal settlements: co-production of public services for inclusive governance. Local Environment, 21 (12), 1557-1572

Pádua Bosi, A. de (2015) História dos catadores no Brasil. São Paulo: Ediçōes Verona.

Perry S. E. (1978) San Francisco scavengers dirty work and the pride of ownership. University of California press, Berkeley, CA.

Pisano, V.; Demajorovic, J. \& Besen, G. R. (2019) Cooperação nas redes de empreendimentos de catadores de materiais recicláveis. $X X$ Engema- Encontro Internacional sobre Gestão Empresarial e Meio Ambiente. São Paulo. FEA /USP., p.335-350. Retrieved from: http:// engemausp.submissao.com.br/20/anais/resumo.php?cod_trabalho=335

Reis, M. F.; Conti, M. D. \& Correa, M. R. M. (2015) Gestão de Resíduos Sólidos: Desafios e Oportunidades para a Cidade de São Paulo. RISUS - Journal on Innovation and Sustainability, 6 (3), 77-96. 
Rodrigues, G., Azevedo, A. \& Gutberlet, J. (2015) Parcerias Público-Privadas no Tratamento de Resíduos Sólidos. Opções e impactos socioambientais no Caso de São Bernardo do Campo/SP. In Serie Ciclo de Debates Alianças Público-Privadas para o Desenvolvimento: Experiências brasileiras e desafios para fortalecimento de Alianças Público-Privadas para o Desenvolvimento. Banco Interamericano de Desenvolvimento. Brasília: IDB, ISBN: 978-8599515-20-4, 173--187.

Rutkowski, J. E. (2013) Redes solidárias de catadores e gestão de resíduos sólidos. Revista Tecnologia e Sociedade, 9 (18), Special Edition. DOI: 10.3895/rts.v9n18

Rutkowski, J. E. \& Rutkowski, E. W. (2015) Expanding worldwide urban solid waste recycling: The Brazilian social technology in waste pickers inclusion. Waste Management \& Research. 33 (12), 10841093.

Samson, M. (2009) Refusing to be Cast Aside: Waste pickers organizing around the world. Cambridge: WIEGO.

Scheinberg, A. (2012) Informal Sector Integration and High Performance Recycling: Evidence from 20 Cities. WIEGO Working Paper (Urban Policies) N 23 March 2012.

Scheinberg, A.; Spies, S.; Simpson, M.H. \& Mol, P.J. (2011) Assessing urban recycling in low- and middle-income countries: Building on modernized mixtures. Habitat International, 35, 188-198.

Sembiring, E. \& Nitivattananon V. (2010) Sustainable solid waste management toward an inclusive society: Integration of the informal sector. Resources, Conservation and Recycling. 54, 802-809.

Singer, P. (2002) A recente ressurreição da economia solidária no Brasil. In: SOUZA SANTOS (Org.). Produzir para viver: os caminhos da produção não capitalista. Rio de Janeiro: Civilização Brasileira.

Tavares Campos, H. K. (2014) Recycling in Brazil: Challenges and prospects. Resources, Conservation and Recycling 85, 130- 138.

Tirado-Soto, M. M. \& Zamberlan, F. L. (2013) Networks of recyclable material waste-picker's cooperatives: an alternative for the solid waste management in the city of Rio de Janeiro. Waste Management, 33, 1004-1012

Trembley, C. (2009) Advancing the social economy for socio-economic development: international perspectives. In: Canadian Social Economy Research Partnerships - Public Policy Papers Series, No. 1.
UN - Environment (2019) Global Environment Outlook GEO- 6, Healthy Planet, Healthy people. Cambridge. DOI: 10.1017/9781108627146.

UN-Environment Program (UNEP) \& International Solid Waste Association (ISWA) (2015) Global waste management outlook. Able at:

https://www.unenvironment.org/resources/report/global-waste-management-outlook

UN-HABITAT (2010) Solid waste management in the world's cities: Highlights from the UN-Habitat 2010 book. Retrieved from: http://www. waste.nl/en/product/solid-waste-management-in-the-world-cities

UN - United Nations (2007) Indicators of Sustainable Development: Guidelines and Methodologies. Third Edition, United Nations New York.

UN Inter-Agency Task Force on Social and Solidarity Economy (2018) Mapping of intergovernmental documentation on Social and Solidarity economy. Knowledge Hub resources, V.1, UNRISID. May 2018. Retrieved from: http://unsse.org/wp-content/uploads/2018/05/UNTFSSE-KH-Resources-Mapping-of-Intergovernmental-Documentation-on-Social-and-Solidarity-EconomySSE.pdf

Velis, C.A. (2017) Waste pickers in Global South: Informal recycling sector in a circular economy era. Waste Management \& Research, 35 (4), 329-331.

Velis, C. A.; Wilson, D. C. ; Rocca, O.; Smith, S. R.; Mavropoulos, A. \& Cheeseman, C. R. (2012) An analytical framework and tool ('InteRA') for integrating the informal recycling sector in waste and resource management systems in developing countries. Waste Management \& Research. 30 (43), 43-66.

Vieira, F. M. (2005) Coerência e aderência da economia solidária: um estudo de caso dos coletivos de produção do MST em Mato Grosso do Sul / Fabiano Mourão Vieira. -- São Paulo, 2005. 456 p. (PhD Thesis) - Universidade de São Paulo.

Wilson, D. C., Rodic, L., Modak, P. et alli. (2015) Global Waste Management Outlook. Report. UNEP/ISWA.

Wilson, D.; Rodic, L.; Scheinberg, A.; Velis, C. \& Alabaster, G. (2012) Comparative Analysis of Solid Waste Management in 20 Cities. Waste Management and Research 30 (3), 237-254.

Wilson, D.; Velis, C. \& Cheeseman, C. (2006) Role of informal sector recycling in waste management in developing countries. Habitat International 30, 797-808. 